\title{
Hubungan Pelaksanaan Timbang Terima dengan Keselamatan Pasien oleh Perawat Pelaksana
}

\author{
Anisa Wisdayana, Efroliza, Anita Apriany
}

STIKes Muhammadiyah Palembang, Program Studi Ilmu Keperawatan, Jl. Jenderal Ahmad Yani, 13 Ulu, Kecamatan Seberang Ulu II, Kota Palembang, Sumatera Selatan

Email: anisasm43@gmail.com

$\begin{array}{ll}\text { Diterima tanggal } & : \text { 31 Januari } 2020 \\ \text { Direvisi tanggal } & : \text { 21 Maret 2020 } \\ \text { Dipublikasikan tanggal } & : \text { 11 Juni } 2020\end{array}$

\begin{abstract}
Abstrak
Latar Belakang dan Tujuan: Pelaksanaan timbang terima dengan keselamatan pasien bagi perawat pelaksana dapat mewujudkan keselamatan pasien dalam pelayanan keperawatan di rumah sakit. Jika keselamatan pasien telah dilakukan dengan baik dan efektif maka mutu pelayanan keperawatan melalui aspek keselamatan pasien akan semakin meningkat dan berkualitas. Penelitian ini bertujuan untuk mengetahui hubungan pelaksanaan timbang terima dengan keselamatan pasien oleh perawat pelaksana di Ruang Rawat Inap Rumah Sakit Bhayangkara Palembang.

Metode: Penelitian kuantitatif dengan pendekatan cross sectional dan desain deskriptif analitik. Teknik pengambilan sampel dengan total Sampling sebanyak 43 responden. Instrumen penelitian menggunakan kuesioner. Teknik analisis data dengan cara univariat dan bivariat dengan menggunakan Chi Square.

Hasil: Berdasarkan hasil penelitian didapatkan pelaksanaan timbang terima baik sebanyak $65,1 \%$ dan keselamatan pasien baik sebanyak 53,5\%. Dengan hasil uji statistik Chi Square yang dilakukan diperoleh nilai (P value 0,000 < 0,05)

Simpulan dan Implikasi: Ada hubungan pelaksanaan timbang terima dengan keselamatan pasien oleh perawat pelaksana di Ruang Rawat Inap RS Bhayangkara Palembang. Penelitian ini diharapkan dapat merancang suatu standar atau prosedur operasional atau uraian tugas khusus timbang terima terkait dengan keselamatan pasien yang dilakukan oleh perawat pelaksana.
\end{abstract}

Kata Kunci: Keselamatan pasien; Perawat pelaksana; Timbang terima

Sitasi: Wisdayana A, Efroliza \& Apriany A. (2020). Hubungan pelaksanaan timbang terima dengan keselamatan pasien oleh perawat pelaksana. The Indonesian Journal of Health Science. 12(1), 83-90

Copyright: () 2020 Wisdayana et al. This is an open-access article distributed under the terms of the Creative Commons Attribution License, which permits unrestricted use, distribution, and reproduction in any medium, provided the original author and source are credited.

Diterbitkan Oleh: Universitas Muhammadiyah Jember

ISSN (Print): 2087-5053

ISSN (Online): 2476-9614 


\begin{abstract}
Backgrpund and Aim: Operan shift implementation with patient safety for executive nurses can realize patient safety in nursing services in hospitals. If the patient's safety has been done well and effectively, the quality of nursing services through the aspect of patient safety will increase and quality. The aim of this research it was to determine the relationship of operan shift implementation with patient safety by the nurse in the Inpatient Room of Bhayangkara Hospital Palembang.

Method: It used quantitative research with cross sectional approach and descriptive analytic design.Sampling technique used a total sampling of 43 respondents. The research instrument used a questionnaire. Data analysis techniques used univariate and bivariate methods using Chi Square.

Results: Based on the results of the study it was found that the good operan shift implementation was $65,1 \%$. And good patient safety was 53,5\%. With the results of the Chi Square statistical test carried out obtained a value of (P-value $0.000<$ 0.05 ).

Conclusion: There was a relationship between the operan shift implementation and patient safety by the nurse in the Inpatient Room of Bhayangkara Hospital Palembang. This Research is expected could design a standard or operational procedure or a special description of the accepting tasks related to patient safety carried out by implementing nurses.
\end{abstract}

Keywords: Nurse, Operan shift; Patient safety

\section{PENDAHULUAN}

\begin{tabular}{lrr}
\multicolumn{1}{c}{ Rumah } & Sakit & merupakan \\
organisasi & yang & memberikan \\
pengobatan & & secara \\
berkesinambungan & kepada & pasien
\end{tabular} yang sakit melalui tenaga profesional yang terorganisir meliputi sarana kedokteran, asuhan keperawatan, diagnosa, serta pengobatan yang berkualitas (WHO, 2013). Sedangkan menurut Peraturan Menteri Kesehatan Republik Indonesia Nomor 4 Tahun 2018 tentang kewajiban Rumah Sakit dan Kewajiban Pasien adalah Rumah sakit merupakan institusi pelayanan kesehatan yang menyediakan pelayanan kesehatan perorangan secara paripurna yang menyediakan pelayanan rawat jalan, rawat inap, serta gawat darurat.

Mutu pelayanan keperawatan adalah indikator kualitas pelayanan kesehatan yang merupakan faktor penentu citra institusi pelayanan kesehatan di mata masyarakat. Mutu pelayanan kesehatan di rumah sakit sangat dipengaruhi oleh kualitas sarana fisik, jenis tenaga yang tersedia, obat dan alat kesehatan, serta proses pemberian pelayanan. Mutu pelayanan kesehatan merupakan tingkat pelayanan kesehatan yang diberikan kepada pasien dengan kesempurnaan berdasarkan standar profesi dengan memanfaatkan sumber daya yang ada secara baik, sehingga dapat mencapai derajat kesehatan secara optimal (Azwar, 2014).

Upaya peningkatan pelayanan kesehatan, tidak lepas dari pelayanan keperawatan yang berkesinambungan dengan mempromosikan perawatan yang baik sesuai standar professional dan 
hukum (College of registered nurses of BritishColumbia). Salah satu bentuk pelayanan yang diberikan kepada pasien adalah melalui pemberian asuhan keperawatan, pengobatan dan rasa aman bagi pasien, keluarga serta masyarakat (Aditama, 2016).

Keselamatan pasien adalah variabel yang dapat mengukur serta mengevaluasi kualitas pelayanan keperawatan yang akan berdampak terhadap pelayanan kesehatan. Program keselamatan pasien ditujukan untuk menurunkan angka Kejadian yang Tidak Diharapkan (KTD) yang sering terjadi pada pasien selama dirawat di rumah sakit sehingga merugikan baik pasien sendiri dan pihak rumah sakit (Nursalam, 2014.) Pemberian asuhan keperawatan yang aman kepada pasien dapat mencegah terjadinya KTD

World Health Organization (WHO), 2014 Keselamatan pasien merupakan masalah keseahatan masyarakat global yang serius. Di Eropa mengalami pasien dengan resiko infeksi $83,5 \%$ dan bukti kesalahan medis menunjukkan 5072,3\%. Di kumpulkan angka-angka penelitian rumah sakit di berbagai Negara, ditemukan KTD dengan rentang 3,2-16,6\%.

Pada tahun 2015, kesalahan medis (medical error) menjadi penyebab kematian ketiga di Amerika Serikat, sekitar lebih dari 250.000 kematian per tahun. Survei terbaru tahun 2017 masih menemukan sekitar $21 \%$ pasien memiliki pengalaman kesalahan medis. Ketika kesalahan medis terjadi, itu turut berdampak pada kesehatan fisik dan emosional pasien, finansial/keuangan serta hubungan keluarga. Di Amerika
Serikat, setiap tahun 1 dari 20 orang dewasa mengalami kesalahan diagnostik (diagnostic error). Insiden pelanggaran patient safety $28,3 \%$ dilakukan oleh perawat. Di Indonesia, penelitian Utarini et al. menunjukkan bahwa angka KTD sangat bervariasi, untuk kesalahan diagnosis yaitu $8,0 \%$ hingga $98,2 \%$ dan kesalahan pengobatan sebesar $4,1 \%$ hingga $91,6 \%$. Terus berkembangnya penelitian tentang keselamatan pasien diberbagai daerah, namun sampai saat ini belum ada studi nasional.

Asfek yang sangat penting yang harus diperhatikan perawat pada saat melakukan timbang terima (handover) adalah komunikasi antar perawat dalam menyampaikan kondisi dan tindakan yang akan dilakukan kepada pasien dengan tujuan untuk mencegah kesalahan yang dilakukan oleh perawat. Dari penelitian Dewi Mursidah, (2015) menemukan bahwa kurangnya komunikasi akan menimbulkan ancaman terhadap keselamatan pasien dan kualitas perawatan. Penelitian tersebut didukung oleh Alvarado et al. yang mengatakan bahwa sebanyak $70 \%$ kejaadian yang mengakibatkan kematian dan cedera serius disebabkan oleh buruknya komunikasi antar perawat. Ghufron menginformasikan bahwa timbang terima (handover) sangat membantu dalam perawatan pasien. timbang terima pasien dirancang sebagai salah satu metode komunikasi yang relevan pada tim perawat setiap pergantian shift, sebagai petunjuk praktik memberikan informasi mengenai kondisi terkini pasien, tujuan pengobatan, rencana perawatan serta menentukan prioritas pelayanan 


\begin{abstract}
Berdasarkan penelitian Manopo (2013) mengungkapkan bahwa kategori kurang baik mengenai penerapan timbang terima pasien oleh responden ada $36,7 \%$ dan kategori baik ada 63,3\%. Data pada penerapan keselamatan pasien, ada $28,3 \%$ responden yang termasuk pada kategori kurang baik dan ada $71,7 \%$ responden yang termasuk pada kategori baik. Bila timbang terima tidak dilakukan dengan baik, maka akan muncul kerancuan dari tindakan keperawatan yang diberikan karena tidak adanya informasi yang bisa digunakan sebagai dasar pemberian tindakan keperawatan. Hal ini akan menurunkan kualitas pelayanan keperawatan dan berdampak pada keselamatan pada pasien.
\end{abstract}

Rumah Sakit Bhayangkara Palembang adalah rumah sakit yang diklasifikasikan sebagai Rumah Sakit Bhayangkara tingkat III yang sekurang-kurangnya mampu memberikan pelayanan kesehatan terdiri dari Instalasi Gawat Darurat, Instalasi Rawat Jalan, terdiri dari 17 klinik umum dan spesialis, Instalasi Bedah Sentral, Instalasi Rawat Inap, Pelayanan Trauma Center, Kompartemen Kedokteran Kepolisian (Dokpol), Pelayanan pemeriksaan penunjang medik; berupa pelayanan radiologi, laboratorium (melalui $\mathrm{KSO}$ ), fisiotherapy, CT SCAN, Haemodialisa dan Tread Mill, Pelayanan penunjang non medik; berupa laundry, pengolahan limbah, ambulance klinik dan transportasi, sarana parkir dan kantin dan BPJS center

Studi pendahuluan yang dilakukan oleh peneliti di RS. Bhayangkara Palembang bertujuan untuk mengetahui pelaksanaan timbang terima dengan keselamatan pasien di ruang rawat inap RS. Bhayangkara Palembang yang dilakukan dengan cara observasi lapangan dan Wawancara.

Dari hasil wawancara terhadap kepala ruangan di rumah sakit bhayangkara, kepala ruangan ikut dan memimpin pembukaan dalam melakukan timbang terima. Di setiap ruangan rawat inap terdapat SOP untuk melakukan timbang terima, tetapi tidak semua ruangan sudah melakukan timbang terima sesuai dengan keseluruhan SOP yang ada. Timbang terima biasanya dilakukan dengan cara verbal, tertulis dan bedside handover.

Berdasarkan hasil studi pendahuluan yang dilakukan oleh peneliti ditemukan data keselamatan pasien sebanyak $0,5 \%$ angka Kejadian Tidak Diharapkan (KTD) setiap tahunnya. Hasil wawancara terhadap Kepala Bidang Keperawatan Rumah Sakit Bhayangkara Palembang diketahui bahwa angka kejadian keselamatan pasien terbilang cukup tinggi hal ini dikarenakan oleh banyak faktor salah satunya adalah pelaksanaan timbang terima yang sesuai dengan SOP yang berlaku.

Dari uraian latar belakang tersebut, peneliti tertarik dan berkeinginan untuk mengetahui dan menganalisis "Hubungan Pelaksanaan Timbang Terima Pasien Dengan Keselamatan Pasien Oleh Perawat Pelaksana diruang rawat inap RS. Bhayangkara Palembang tahun 2019".

\section{METODE PENELITIAN}

Jenis penelitian yang dilakukan pada penelitian ini yaitu penelitian kuantitatif dengan pendekatan cross sectional study dengan desain 
penelitian deskriptif analitik. Teknik pengambilan sampel dengan cara total sampling yang berjumlah 43 responden dengan kriteria inklusi yakni bersedia menjadi responden, perawat yang bekerja diruang rawat inap Rumah Sakit Bhayangkara Palembang tahun 2019, perawat yang berstatus aktif dalam bekerja dan tidak dalam masa cuti.

Instrumen yang digunakan pada penelitian ini yaitu kuesioner yang telah diuji validitas dan reliabilitas. Jumlah pernyataan yang digunakan yaitu sebanyak 16 pernyataan untuk kuesioner timbang terima serta 24 pernyataan untuk keselamatan pasien.

Teknik pengumpulan data yang digunakan dengan cara data primer yaitu data yang didapatkan langsung dari responden dengan cara pembagian kuesioner serta data sekunder yaitu data yang didapatkan dari data rumah sakit yang berupa jumlah perawat ruang rawat inap dan indikator mutu pelayanan Rumah Sakit Bhayangkara Palembang.

Teknik pengolahan data dilakukan dengan cara mengentri data dari kuesioner ke paket program komputer yang menggunakan Chi Square Test untuk menjawab hipotesa hubungan pelaksanaan timbang terima dengan keselamatan pasien oleh perawat pelaksana.

\section{HASIL}

Karakteristik responden dalam penelititan ini pada populasi 43 responden yang terdiri atas ruang JN I, JN II, Suparto, dan ruang cendana. Hasil dari tabel 1 menunjukkan bahwa sebanyak 28 responden $(65,1 \%)$ perawat pelaksana kategori baik untuk timbang terima dan sebanyak 15 responden $(34,9 \%)$ perawat pelaksana kategori kurang baik untuk timbang terima. Hasil dari tabel 2 menunjukkan bahwa sebanyak 23 responden $(53,5 \%)$ keselamatan pasien kategori baik dan sebanyak 20 responden $(46,5 \%)$ keselamatan pasien kategori kurang baik. Hasil dari tabel 3 menunjukkan bahwa nilai $\mathrm{P}$ value $0,00>0,05$ hal ini berarti ada hubungan antara timbang terima dengan keselamatan pasien.

Tabel 1. Distribusi Frekuensi Responden Berdasarkan Kategori Timbang Terima

\begin{tabular}{ccc}
\hline \multicolumn{1}{c}{ Timbang Terima } & f & \% \\
\hline Baik & 28 & 65,1 \\
Kurang Baik & 15 & 34,9 \\
\hline Jumlah & $\mathbf{4 3}$ & $\mathbf{1 0 0 \%}$ \\
\hline
\end{tabular}

Tabel 2. Distribusi Frekuensi Responden Berdasarkan Kategori Keselamatan Pasien

\begin{tabular}{lccc}
\hline \multicolumn{1}{c}{ Keselamatan Pasien } & f & \% \\
\hline Baik & 23 & & 53,5 \\
Kurang Baik & 20 & & 46,5 \\
\hline \multicolumn{1}{c}{ Jumlah } & $\mathbf{4 3}$ & $\mathbf{1 0 0 \%}$ & \\
\hline
\end{tabular}


Tabel 3. Hubungan Pelaksanaan Timbang Terima dengan Keselamatan Pasien

\begin{tabular}{cccccccc}
\hline \multirow{2}{*}{$\begin{array}{c}\text { Timbang } \\
\text { Terima }\end{array}$} & \multicolumn{6}{c}{ Baik } & \multicolumn{3}{c}{ Kurang Baik } & \multicolumn{2}{c}{ Total } & \multirow{2}{*}{ Nilai P ( $\boldsymbol{p}$ value) } \\
\cline { 2 - 7 } & $\mathbf{N}$ & $\mathbf{\%}$ & $\mathbf{N}$ & $\mathbf{\%}$ & $\mathbf{n}$ & $\mathbf{\%}$ & \\
\hline Baik & 22 & 78,6 & 6 & 21,4 & 28 & 100 & \\
Kurang Baik & 1 & 6,7 & 14 & 93,3 & 15 & 100 & 0,000 \\
\hline Jumlah & $\mathbf{2 3}$ & $\mathbf{5 3 , 5}$ & $\mathbf{2 0}$ & $\mathbf{4 6 , 6}$ & $\mathbf{4 8}$ & $\mathbf{1 0 0}$ & \\
\hline
\end{tabular}

\section{PEMBAHASAN}

Berdasarkan hasil penelitian didapatkan pelaksanaan timbang terima baik sebanyak 78,6\%. Sedangkan sebanyak 15 responden mengatakan timbang terima kurang baik dengan keselamatan pasien sebanyak 14 responden 93,3\%. Dari hasil uji yang dilakukan diperoleh nilai $\mathrm{P}$ value $(0,000)<0,05$, hal ini dapat disimpulkan bahwa ada hubungan antara timbang terima dengan keselamatan pasien oleh perawat pelaksana di Ruang Rawat Inap RS. Bhayangkara Palembang Tahun 2018 dengan nilai OR sebesar 51,333. Dalam hal ini berarti timbang terima yang baik mempunyai peluang 51,333 kali untuk perawat pelaksana melakukan pelakasaan keselamatan pasien secara baik.

Menurut Alverado, et.al. (2006), adanya komunikasi yang terintegrasi dengan keselamatan pasien dalam timbang terima dan disosialosasikan secara menyeluruh pada perawat pelaksana akan meningkatkan efektifitas dan koordinasi dalam menginformasikan hal penting sehingga berkesinambungan pelayanan dalam mendukung keselamatan pasien. The Joint Commision on Acreditation of Health Care Organization menerapkan komunikasi dalam timbang terima menjadi aspek penting dalam perawatan pasien untuk menjamin keselamatan pasien, sebagai salah satu strategi untuk mengurangi Kejadian Tidak Diharapkan (KTD), Kejadian Nyaris Cidera (KNC) serta sentinel even.

Kebijakan dan standar pelaksanaan timbang terima dapat meningkatkan efektivitas komunikasi dalam timbang terima pasien, peningkatan berfikir kritis perawat, efektivitas waktu meninggalkan pasien pada saat pelaksanaan timbang terima, serta mengidentifikasi kesalahan yang dapat terjadi pada pasien sehingga meningkatkan keselamatan pasien (WHO, 2007).

Timbang terima harus dilakukan seefektif mungkin dengan penjelasan yang jelas, akurat, dan lengkap untuk menunjang keberlangsungan asuhan keperawatan dapat berjalan dengan baik. Informasi dalam pemberian pelayanan kesehatan pun berkesinambungan tidak terjadi salah presepsi yang dapat berujung kesalahan dan menimbulkan kerugian pada pasien (Nursalam, 2016).

Menurut Dewi dalam Cecep Triwibowo (2016) mengatakan bahwa keselamatan pasien terlindungi melalui standar keselamatan pasien dan peningkatan penerapan keselamatan pasien oleh perawat melalui enam penerapan keselamatan salah satunya yaitu komunikasi efektif pada saat timbang terima. 
Hasil penelitian Quiteria Manopo yang berjudul hubungan antara penerapan timbang terima pasien dengan keselamatan pasien oleh perawat pelaksana di RSU GMIM Kalooran Amurang menunjukkan, kategori baik mengenai penerapan timbang terima pasien oleh responden ada 63,3\%, sedangkan data pada penerapan keselamatan pasien, ada $71,7 \%$ responden yang termasuk pada kategori baik dan ada. Hasil analisis bivariat menunjukkan $\mathrm{p}=0,000$ $(\alpha<0,05)$ sehingga dapat disimpulkan bahwa adanya hubungan antara penerapan timbang terima pasien dengan keselamatan pasien oleh perawat pelaksana di RSU GMIM Kalooran Amurang (Quiteria Manopo, 2013).

Sedangkan hasil penelitiaan Triwibowo yang berjudul handover sebagai upaya peningkatan keselamatan pasien (patient safety) di rumah sakit, didapatkan nilai $\mathrm{P}$ value : 0,040 artinya terdapat hubungan yang signifikan antara pelaksanaan timbang terima dengan keselamatan pasien. Hal ini karena 0,040 lebih kecil dari $0,05(\mathrm{P} \leq 0,05)$ dapat disimpulkan bahwa terdapat hubungan antara pelaksanaan timbang terima dengan keselamatan pasien. Baik buruknya pelaksanaan timbang terima dapat mempengaruhi keselamatan pasien (Triwibowo, 2016). Sejalan dengan hasil penelitian Mursidah Dewi yang berjudul pengaruh pelatihan timbang terima pasien terhadap penerapan keselamatan pasien oleh perawat pelaksana di RSUD Raden Mattaher Jambi, bahwa terdapat peningkatan terhadap pelaksanaan timbang terima pasien dan penerapan keselamatan pasien sesudah perawat pelaksana diberikan pelatihan timbang terima (pvalue : 0.000, $\alpha: 0.05$ ) (Mursidah Dewi 2012).

Dari penelitian yang dilakukan oleh Cecep Triwibowo yang berjudul studi kualitatif: peran handover dalam meningkatkan keselamatan pasien di rumah sakit, menunjukkan bahwa mayoritas perawat belum menerapkan timbang terima sangat meskipun keselamatan pasien menjadi prioritas dalam asuhan keperawatan. Untuk itu agar pelaksanaan handover dapat berjalan dengan baik serta keselamatan pasien terlindungi diperlukan adanya pelatihan tentang handover, supervisi tiap ruangan, adanya tanggung jawab, kerjasama, motivasi, dan komunikasi antar perawat serta sitem pelaporan yang adekuat, kejujuran dan keterbukaan serta mengubah budaya dari blaming cultur menjadi safety cultur. (Cecep Triwibowo, 2016)

\section{SIMPULAN}

Ada hubungan pelaksanaan timbang terima dengan keselamatan pasien oleh perawat pelaksana di Ruang Rawat Inap RS Bhayangkara Palembang.

\section{SARAN}

Bagi Rumah Sakit diharapkan dapat merancang suatu standar atau prosedur operasional atau uraian tugas khusus timbang terima terkait dengan keselamatan pasien yang dilakukan oleh perawat pelaksanaan.

\section{DAFTAR PUSTAKA}

Aditama. Manajemen Administrasi Rumah Sakit. Jakarta: Universitas Indonesia; 2016.

Alverado, K., et.al. (2006). Transfer Of Accountability 
Transforming shift handover to enhance patient safety. Health Care Quartely. Special Issue.

Azwar, S. (2014). Sikap manusia: Teori dan pengukurannya.Jakarta: Pustaka Pelajar

Mursidah, Dewi. 2012. Pengaruh Pelatihan Timbang Terima Pasien Terhadap

Penerapan Keselamatan Pasien Oleh Perawat Pelaksana di RSUD Raden Mattaher Jambi. Jurnal Health \& Sport, Vol. 5(3), Agustus 2012: 651-652 diakses 18 Maret 2019 Ghufron,

Muhamad (2016). Pengaruh Benban Kerja Perawat Terhadap Pelaksanaan Timbang Terima Perawat di Ruang Rawat Inap Rumah Sakit Wava Husada Kepanjen Malang. Skripsi Universitas Muhamadiyah Malang.

Join Commission International. (2015). Acreditation Standard For Hospital. 4th Editon. USA : Saunders, Elsevier Inc

Komite Keselamatan Pasien Rumah

Sakit (Kkprs). 2015.

Pedoman Pelaporan Insiden Keselamatan Pasien (IKP) (Patient Safety Incident Report). Jakarta : KKPRS

Manopo, Quiteria, Frangky, R.R.M., Jehosua, S.V.S. 2013. Hubungan antara PenerapanTimbang Terima Pasien dengan Keselamatan Pasien oleh Perawat Pelaksana di RSU GMIM Kalooran Amurang. http//:fkm.unsrat.ac.id

Diakses 24 Maret 2019

Peraturan Menteri Kesehatan Republik Indonesia Nomor 4 Tahun $2018 \quad$ Tentang Kewajiban Rumah Sakit Dan Kewajiban Pasien

Profil Rumah Sakit Bhayangkara Tahun, 2018

Triwibowo, C. dkk. 2016. Handover Sebagai Upaya Peningkatan Keselamatan Pasien (Patient Safety) Di Rumah Sakit. Jurnal Keperawatan Soedirman (The Soedirman Journal of Nursing), 11(2) :78-79

Triwibowo,C.(dkk, 2016. Studi Kualitatif: Peran Handover Dalam Meningkatkan Keselamatan Pasien Di Rumah Sakit. Jurrnal Pena Medika. Vol. 6(2), Desember $2016: 77-78$

Wiwik D, Arianti. (2014). Penerapan Timbang Terima Pasien dengan Keselamatan Pasien Oleh Perawat Pelaksana di Ruang Rawat Bedah dan Ruang Penyakit dalam RSUD Dr Pringadi Medan.

World Health Organization (2014) 10 fact of patient safety. Diakses dari World Health Organization website: http://www.who.int/features/f actfiles/patient_safety/en/

World Health Organization (WHO), WHO Guiding Principles On Human Cell, Tissue, and Organ Transplation Accessed Jun 23, 2013. http://www.who.int/transplant ation/Guiding_PrinciplesTran splantation_WHA63.22en.pdf 